\title{
Advances in understanding cartilage remodeling [version 1;
}

\section{peer review: 2 approved]}

\author{
Yefu $\mathrm{Li}^{1,2}$, Lin $\mathrm{Xu} \mathrm{u}^{1,2}$ \\ ${ }^{1}$ Department of Developmental Biology, Harvard School of Dental Medicine, Boston, MA, USA \\ ${ }^{2}$ Faculty of Medicine, Harvard Medical School, Boston, MA, USA
}

V1 First published: 28 Aug 2015, 4(F1000 Faculty Rev):642

https://doi.org/10.12688/f1000research.6514.1

Latest published: 28 Aug 2015, 4(F1000 Faculty Rev):642

https://doi.org/10.12688/f1000research.6514.1

\begin{abstract}
Cartilage remodeling is currently among the most popular topics in osteoarthritis research. Remodeling includes removal of the existing cartilage and replacement by neo-cartilage. As a loss of balance between removal and replacement of articular cartilage develops (particularly, the rate of removal surpasses the rate of replacement), joints will begin to degrade. In the last few years, significant progress in molecular understanding of the cartilage remodeling process has been made. In this brief review, we focus on the discussion of some current "controversial" observations in articular cartilage degeneration: (1) the biological effect of transforming growth factorbeta 1 on developing and mature articular cartilages, (2) the question of whether aggrecanase 1 (ADAMTS4) and aggrecanase 2 (ADAMTS5) are key enzymes in articular cartilage destruction, and (3) chondrocytes versus chondron in the development of osteoarthritis. It is hoped that continued discussion and investigation will follow to better clarify these topics. Clarification will be critical for those in search of novel therapeutic targets for the treatment of osteoarthritis.
\end{abstract}

\section{Keywords}

Cartilage remodeling, osteoarthritis, transforming growth factor-

beta 1 , aggrecanase, chondrocytes, chondron

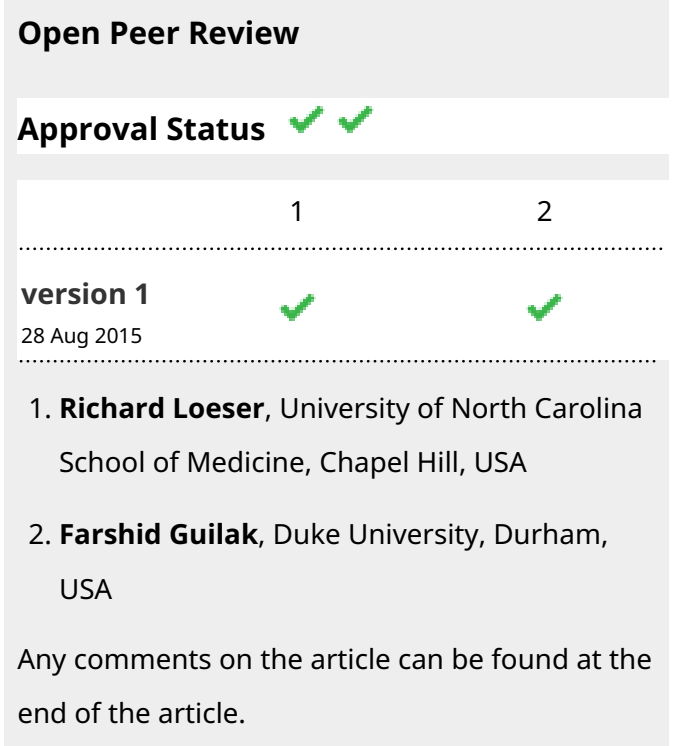

Corresponding author: Yefu Li (yefu_li@hms.harvard.edu)

Competing interests: The authors declare that they have no competing interests.

Grant information: The author(s) declared that no grants were involved in supporting this work.

Copyright: $\odot 2015 \mathrm{Li} \mathrm{Y}$ and Xu L. This is an open access article distributed under the terms of the Creative Commons Attribution License, which permits unrestricted use, distribution, and reproduction in any medium, provided the original work is properly cited.

How to cite this article: $\mathrm{Li} Y$ and $\mathrm{Xu}$ L. Advances in understanding cartilage remodeling [version 1; peer review: 2 approved] F1000Research 2015, 4(F1000 Faculty Rev):642 https://doi.org/10.12688/f1000research.6514.1

First published: 28 Aug 2015, 4(F1000 Faculty Rev):642 https://doi.org/10.12688/f1000research.6514.1 
Cartilage remodeling is a continuous process in which the existing cartilage is removed (or degraded) and replaced by new cartilage (regenerated). The balance between degradation and regeneration has been considered so critical that tipping the scale toward degradation results in osteoarthritis (OA). Therefore, an understanding of the molecular basis of the degradation and regeneration processes will undoubtedly provide valuable information for those in search of novel therapeutic protocols for the treatment of OA. In this review article, we focus on several recent discoveries on the topic of articular cartilage degeneration.

With regard to the remodeling of the extracellular matrix, mature articular cartilages are, in general, considered relatively quiescent tissues. For example, a study by Verzijl et al. indicates that the halflife of collagens in human mature cartilages is 117 years $^{1}$. The long half-life of the collagens indicates a slow turnover of the collagens in the cartilages. However, the half-life of the aggrecan (the large monomer) turnover is about 3.4 years $^{2}$. This suggests that the rate of the turnover may be different in the different parts of the extracellular matrix. For example, the rate of the turnover is high in the aggrecan-rich pericellular matrix of chondrocytes and the rate of the turnover is low in the collagen-rich interterritorial and territorial matrices in articular cartilages ${ }^{3}$.

Although this review focuses on articular cartilages, we have to point out that $\mathrm{OA}$ is currently considered the consequence of the whole joint failure. In addition to articular cartilages, the subchondral bone, peri-articular cartilage, synovial membrane, ligaments, and menisci contribute to the development of $\mathrm{OA}^{4}$.

\section{Biological effect of transforming growth factor-beta $1 \beta$ on developing and mature articular cartilages}

Is transforming growth factor-beta 1 (TGF- $\beta 1$ ) a culprit or protector in the development of OA? Currently, numerous pharmaceutical companies are considering the use of TGF- $\beta 1$ as a stimulant to repair damaged articular cartilage for the treatment of OA. Is this the correct choice?

TGF- $\beta 1$ has been considered an anabolic factor to articular chondrocytes, based largely on results from in vitro and ex vivo experiments in which TGF- $\beta 1$ can stimulate chondrocytes to synthesize and release proteoglycans and type II collagens ${ }^{5,6}$. In addition, three independent mouse genetic studies ${ }^{7-9}$ demonstrate that Tgf- $\beta 1$ is required for the formation of articular cartilage at early stages of development in mice. Without Tgf- $\beta 1$, articular cartilage is not formed properly, eventually an immature joint becomes an OA-like joint in mice. Moreover, a human genetic study reports that a two-nucleotide deletion, 741-742del AT (nonsense mutation), in $S M A D-3$ causes early-onset OA in a human family ${ }^{10}$. All of the aforementioned results support the argument that TGF- $\beta 1$ is a protector against the development of OA. Unfortunately, the situation is not that simple. Numerous other independent investigations suggest that TGF- $\beta 1$ may, in fact, be a factor in joint destruction. First, studies with animal models, by Itayem et al., suggest that intraarticular injections of TGF- $\beta 1$ into adult rat knee joints cause early onset of $\mathrm{OA}^{11,12}$. Second, a human genetic study reports that a nucleotide change, $859 \mathrm{C}>\mathrm{T}$ or $782 \mathrm{C}>\mathrm{T}$ in $S M A D$-3, increases the level of TGF- $\beta 1$ and activity of the TGF- $\beta 1$ signaling pathway in human families is associated with early-onset $\mathrm{OA}^{10}$. This is in agreement with the observation from two other studies indicating that the level of TGF- $\beta 1$ is significantly higher in human OA tissues than in healthy articular cartilages ${ }^{13,14}$. Third, we found increases in the expression of Tgf- $\beta 1$ and of $\mathrm{p}-\mathrm{Smad} 2 / 3$ in articular chondrocytes of knee joints in mouse models of $\mathrm{OA}^{15}$. The increased expression of $\mathrm{p}$-Smad2/3 was associated with elevated expression of a serine protease, high-temperature requirement A1 (HtrA1), in the chondrocyte. HTRA1 is capable of degrading extracellular matrix molecules, particularly most pericellular components of articular chondrocytes $^{16}$. Another independent research group also demonstrates that TGF- $\beta 1$ induces HTRA1 in human primary chondrocytes ${ }^{17}$. Fourth, we determined whether the removal of Tgf- $\beta$ type II receptor $(T g f b r 2)$ from the articular cartilage of adult knee joints could attenuate the OA progression. We deleted Tgfbr2 in the articular cartilage of adult mouse knee joints and then subjected the mice to destabilization of the medial meniscus (DMM). We found a significant disparity in the progression of articular cartilage degeneration in knee joints between mice with or without Tgfbr2 at 8 and 16 weeks following the surgery. The progression toward OA was significantly $(P<0.05)$ delayed in $T g f b r 2^{-/-}$mice.

Several studies also indicate that the increase in the amount of TGF- $\beta 1$ in other joint tissues has detrimental effects on adult joints. A study by Maeda et al. suggests that a high level of TGF- $\beta 1$ does more harm than good to the tendon ${ }^{18}$. One study by Bakker et al. reports that the constitutive overexpression of active TGF- $\beta 1$ in adult mouse knee joints results in OA associated with an increase in the production of proteoglycans in articular cartilage, hyperplasia of synovium, and chondro-osteophyte formation ${ }^{19}$. A study by Zhen et al. demonstrates that inhibition of TGF- $\beta 1$ signaling in mesenchymal stem cells of subchondral bone delays the development of OA in adult mice ${ }^{20}$.

How can this "conflicting" role of TGF- $\beta 1$ in the pathogenesis of OA be explained? One plausible explanation is that effective TGF- $\beta 1$ signaling acts in a dose-dependent manner. In this scenario, an appropriate level of TGF- $\beta 1$ is required for the development and maintenance of articular cartilages. Therefore, TGF- $\beta 1$ below or above this level results in articular cartilage degeneration. However, results from our study with mice without $T g f b r 2$ suggest that the TGF- $\beta 1$ dose-dependent manner may not be the case. Another plausible explanation is that effective TGF- $\beta 1$ signaling acts in a developmental stage-dependent manner. In this scenario, TGF- $\beta 1$ is required for the development of articular cartilage; however, once a joint is formed, TGF- $\beta 1$ is no longer needed. In any case, induction of TGF- $\beta 1$ in an adult joint causes articular cartilage degeneration. Therefore, inhibition activity of TGF- $\beta 1$, not application of TGF- $\beta 1$, may be considered in treatment of OA in mature joints.

\section{Are ADAMTS4 and ADAMTS5 key enzymes in articular cartilage destruction?}

Proteoglycans are the basic elements of articular cartilage and are indispensable in the ability of articular cartilage to resist compressive pressure. Thus, much of the effort in the OA research field is focused on the search for an enzyme, or enzymes, that degrades proteoglycan. In 1999, two enzymes, ADAMTS-4 and ADAMTS-5, were cloned $^{21,22}$. Both of these aggrecanases degrade aggrecans 
(proteoglycans). This indicates that both aggrecanases may be ideal therapeutic targets in the development of disease-modifying OA drugs. In fact, two independent research groups used mouse gene-targeting techniques to delete ADAMTS-4 or ADAMTS-5. One group found that the deletion of ADAMTS-5 could protect aggrecan from being degraded in a mouse model of inflammatory arthritis. With regard to the development of OA, it is not clear whether both aggrecanases are involved in cartilage destruction ${ }^{23}$. The results from another group demonstrated that the removal of ADAMTS-5 in mice could significantly delay the progressive process of articular cartilage degeneration at 4-8 weeks following the DMM surgery ${ }^{24}$. This suggests that ADAMTS-5 may play a role in early stages of OA development. However, lack of evidence indicating elevated expression of ADAMTS-5 at early stages of articular cartilage degeneration in any one of the existing mouse models of $\mathrm{OA}$ raises a question as to how important a role this enzyme has in the development of OA.

More importantly, a recent study indicates that the expression of ADAMTS-5 is increased in the articular cartilage of knee joints in adult mice because of inactivation of $\operatorname{Sox} 9^{25}$. The elevated expression of ADAMTS-5 is associated with the disappearance of aggrecans. Surprisingly, there is no progression of articular cartilage degeneration in this model. This is contrary to our current understanding that aggrecans are indispensable for articular cartilage health. Consistent with this observation, another independent investigation indicates that an increase in the expression of bone morphogenetic protein 2 (Bmp2) elevates levels of the neo-epitope, VDIPEN341, of aggrecan in articular cartilage without inducing an acceleration of cartilage degeneration in mice. Furthermore, Davidson et al. find that the increased expression of Bmp2 does not exacerbate the degenerative condition of articular cartilage that has been induced by the DMM in mouse knee joints ${ }^{26}$.

One plausible explanation for the aforementioned observation is that the loss of proteoglycans alone may not be sufficient to initiate or accelerate articular cartilage degeneration. Instead, the degradation of both proteoglycans and type II collagen may be required in the development of OA. Interestingly, a study by Karsdal et al. demonstrates that articular cartilage degradation is completely reversible in the presence of high levels of aggrecanase-mediated aggrecan degradation but irreversible after induction of metalloprotenase (MMP)-mediated aggrecan and collagen type II degradation $^{27}$. This study suggests that the aggrecanases may be involved with the reversible processes of cartilage degradation (or extracellular matrix turnover) but MMPs cause the irreversible degeneration of articular cartilages.

There is evidence that the removal of ADAMTS- 5 may protect joints against OA by stabilizing subchondral bone ${ }^{28}$. Thus, it will be important to understand whether aggrecanases play roles in the development of OA through other joint tissues.

We discuss the aggrecanases in this brief review. However, other enzymes, such as MMPs, elastase, and cathepsins, also play important roles in the pathogenesis of OA.

\section{Chondrocytes versus chondron in the development of osteoarthritis}

Primary chondrocytes and chondrocyte cell lines are the primary tools for in vitro experiments in cartilage research and repair. They have allowed a wealth of information to be obtained about the genetic regulation of chondrocyte function, activation of signaling pathways, and gene expression profiles in chondrocyte response to chemical or mechanical stimulation. Many investigators use chondrocytes in vitro to study physiological and pathophysiological events while mimicking in vivo biological conditions. In particular, researchers almost exclusively use primary chondrocytes as a resource to regenerate functional articular cartilage. Regarding this method, however, a question remains: are primary chondrocytes alone adequate for investigating the role of chondrocytes in $\mathrm{OA}$ development and articular cartilage repair?

Chondrocytes and their pericellular matrix are considered to be the primary structural and functional units, termed chondrons, of articular cartilage ${ }^{29-35}$. This concept was proposed by Benninghoff in 1925. About 40 years later, Szirmai further evaluated the structure of the chondron by a more systematic analysis. At that time, however, the chondron was not widely recognized as a functional unit. Some 20 years later, C.A. Poole's research group completed additional experiments to physically isolate chondrons from cartilage and showed that chondrons are true anatomic and functional entities. Chondrons consist of chondrocytes, the pericellular matrix, and a capsule surrounding the pericellular matrix. The pericellular matrix contains laminin, fibronectin, biglycan, decrin, fibromodulin, matrilin 3, and cartilage oligo matrix protein (COMP). The pericellular capsule is composed mostly of type VI and IX collagen and proteoglycans. The capsule and the pericellular matrix separate chondrocytes from the adjacent interterritorial or territorial matrices containing type II collagen. Clearly, under normal conditions, type II collagen is not exposed to chondrocytes. It is conceivable that disruption of the pericellular matrix exposes chondrocytes to type II collagen and can alter the metabolic events in chondrocytes, eventually leading to cartilage destruction. In fact, results from human and mouse genetic studies indicate the significant role of the pericellular matrix in protecting articular cartilage against the development of OA. For example, the deficiency of one or a combination of two components of the pericellular matrix, such as type VI collagen, type IX collagen, matrilin 3, decrin, biglycan, and fibromodulin, results in early onset of OA in mice ${ }^{36-40}$. In human genetic studies, mutations in type IX collagen and COMP are associated with $\mathrm{OA}^{41-46}$.

In 1998, a study by Lee and Loeser provided evidence that the pericellular matrix of chondrocytes could play critical roles in the maintenance of normal metabolic activities of chondrocytes in articular cartilage and that the disruption of the pericellular matrix is associated with articular cartilage degeneration ${ }^{47}$. Very interestingly, the significant role of the pericellular matrix of a cell is also demonstrated in neural tissue. A study by Gogolla et al. points out that the perineuronal net (pericellular matrix of neurons) in the amygdala plays a significant role in protecting the neurons from the loss of "fear memory" 48 . The authors also find that functional and 
structural changes of sensory systems are caused by the absence of a perineuronal net in the visual cortex. The significant role of the pericellular matrix of a neural cell in the brain coincides with its perceived role within the chondron. If that is the case, maintaining the integrity of the pericellular matrix will be one of the key issues in protection against OA. We believe that more attention should be directed toward the pericellular matrix of chondrocytes for the identification of novel biomarkers and therapeutic targets for OA.

Data from a very recent investigation provide more evidence that chondrons are not only the functional unit in the maintenance of articular cartilage homeostasis but also the basic elements in the regeneration of articular cartilage. Chondrons derived from adult articular cartilage are more efficient than chondrocytes in the regeneration of articular cartilage. This information is particularly critical for the articular cartilage repair field ${ }^{49}$.

Collagen type VI is one of the major components of the capsule of the pericellular matrix. Results from one very recent study indicate that soluble collagen type VI can be a stimulant for chondrocyte proliferation. The soluble collagen type VI may also prevent proliferating chondrocytes from being dedifferentiated in vitro ${ }^{50}$. It is well known that chondrocyte dedifferentiation is one of the major obstacles in cartilage tissue repair. A study by Zelenski et al. shows that the deletion of type VI collagen alters the mechanical properties of the pericellular matrix of chondrocytes ${ }^{51}$. This, in turn, increases the extent of cell swelling and osmotically induced transient receptor potential cation channel subfamily V member 4 (TRPV4) signaling in an age-dependent manner. These findings suggest that alterations in pericellular matrix properties can influence mechanotransduction via TRPV4 or other ion channels, which eventually leads to articular cartilage destruction.

In summary, chondrons, instead of primary chondrocytes or chondrocyte cell lines, may be a more appropriate choice for investigating the biological functions and effects of chondrocytes in the development of OA and cartilage repair.

\section{Competing interests}

The authors declare that they have no competing interests.

\section{Grant information}

The author(s) declared that no grants were involved in supporting this work.
1. F Verzijl N, DeGroot J, Thorpe SR, et al.: Effect of collagen turnover on the accumulation of advanced glycation end products. J Biol Chem. 2000; 275(50) 39027-31.

PubMed Abstract | Publisher Full Text | F1000 Recommendation

2. Maroudas A, Bayliss MT, Uchitel-Kaushansky N, et al.: Aggrecan turnover in human articular cartilage: use of aspartic acid racemization as a marker of molecular age. Arch Biochem Biophys. 1998; 350(1): 61-71. PubMed Abstract | Publisher Full Text

3. Wilusz RE, Sanchez-Adams J, Guilak F: The structure and function of the pericellular matrix of articular cartilage. Matrix Biol. 2014; 39: 25-32. PubMed Abstract | Publisher Full Text | Free Full Text

4. Loeser RF, Goldring SR, Scanzello CR, et al:: Osteoarthritis: a disease of the joint as an organ. Arthritis Rheum. 2012; 64(6): 1697-707. PubMed Abstract | Publisher Full Text | Free Full Text

5. Galéra P, Vivien D, Pronost S, et al.: Transforming growth factor-beta 1 (TGFbeta 1) up-regulation of collagen type II in primary cultures of rabbit articular chondrocytes (RAC) involves increased mRNA levels without affecting mRNA stability and procollagen processing. J Cell Physiol. 1992; 153(3): 596-606. PubMed Abstract | Publisher Full Text

6. van Beuningen HM, van der Kraan PM, Arntz OJ, et al.: Transforming growth factor-beta 1 stimulates articular chondrocyte proteoglycan synthesis and induces osteophyte formation in the murine knee joint. Lab Invest. 1994; 71(2): 279-90.

PubMed Abstract

7. Serra R, Johnson M, Filvaroff EH, et al:: Expression of a truncated, kinasedefective TGF-beta type II receptor in mouse skeletal tissue promotes terminal chondrocyte differentiation and osteoarthritis. J Cell Biol. 1997; 139(2): 541-52. PubMed Abstract | Publisher Full Text | Free Full Text

8. $F$ Yang $X$, Chen $L, X u X$, et al.: TGF-beta/Smad3 signals repress chondrocyte hypertrophic differentiation and are required for maintaining articular cartilage. J Cell Biol. 2001; 153(1): 35-46.

PubMed Abstract | Publisher Full Text | Free Full Text | F1000 Recommendation

9. $\quad F$ Shen J, Li J, Wang B, et al.: Deletion of the transforming growth factor $\beta$ receptor type II gene in articular chondrocytes leads to a progressive osteoarthritis-like phenotype in mice. Arthritis Rheum. 2013; 65(12): 3107-19. PubMed Abstract | Publisher Full Text | Free Full Text | F1000 Recommendation

10. F van de Laar IM, Oldenburg RA, Pals G, et al:: Mutations in SMAD3 cause a syndromic form of aortic aneurysms and dissections with early-onset osteoarthritis. Nat Genet. 2011; 43(2): 121-6.

PubMed Abstract | Publisher Full Text | F1000 Recommendation
11 F Itayem R, Mengarelli-Widholm S, Hulth A, et al.: Ultrastructural studies on the effect of transforming growth factor-beta 1 on rat articular cartilage. APMIS. 1997; 105(3): 221-8.

PubMed Abstract | Publisher Full Text | F1000 Recommendation

12. F Itayem R, Mengarelli-Widholm S, Reinholt FP: The long-term effect of a short course of transforming growth factor-beta1 on rat articular cartilage. APMIS. 1999; 107(2): 183-92.

PubMed Abstract | Publisher Full Text | F1000 Recommendation

13. Schlaak JF, Pfers I, Meyer Zum Büschenfelde KH, et al.: Different cytokine profiles in the synovial fluid of patients with osteoarthritis, rheumatoid arthritis and seronegative spondylarthropathies. Clin Exp Rheumatol. 1996; 14(2): 155-62. PubMed Abstract

14. F Kawamura I, Maeda S, Imamura K, et al.: SnoN suppresses maturation of chondrocytes by mediating signal cross-talk between transforming growth factor- $\beta$ and bone morphogenetic protein pathways. J Biol Chem. 2012; 287(34): 29101-13.

PubMed Abstract | Publisher Full Text | Free Full Text | F1000 Recommendation

15. $\mathrm{Xu} \mathrm{L}$, Golshirazian I, Asbury BJ, et al.: Induction of high temperature requirement A1, a serine protease, by TGF-beta1 in articular chondrocytes of mouse models of OA. Histol Histopathol. 2014; 29(5): 609-18. PubMed Abstract | Publisher Full Text

16. F Grau S, Richards PJ, Kerr B, et al:: The role of human HtrA1 in arthritic disease. J Biol Chem. 2006; 281(10): 6124-9.

PubMed Abstract | Publisher Full Text | F1000 Recommendation

17. F Urano T, Narusawa K, Kobayashi S, et al.: Association of HTRA1 promoter polymorphism with spinal disc degeneration in Japanese women. $J$ Bone Miner Metab. 2010; 28(2): 220-6.

PubMed Abstract | Publisher Full Text | F1000 Recommendation

18. F Maeda T, Sakabe T, Sunaga A, et al.: Conversion of mechanical force into TGF-ק-mediated biochemical signals. Curr Biol. 2011; 21(11): 933-41. PubMed Abstract | Publisher Full Text | Free Full Text | F1000 Recommendation

19. F Bakker AC, van de Loo FA, van Beuningen HM, et al:: Overexpression of active TGF-beta-1 in the murine knee joint: evidence for synovial-layerdependent chondro-osteophyte formation. Osteoarthritis Cartilage. 2001; 9(2): $128-36$.

PubMed Abstract | Publisher Full Text | F1000 Recommendation

20. F Zhen G, Wen C, Jia X, et al.: Inhibition of TGF- $\beta$ signaling in mesenchymal stem cells of subchondral bone attenuates osteoarthritis. Nat Med. 2013; 19(6) 704-12.

PubMed Abstract | Publisher Full Text | Free Full Text | F1000 Recommendation 
21. F Tortorella MD, Burn TC, Pratta MA, et al:: Purification and cloning of aggrecanase-1: a member of the ADAMTS family of proteins. Science. 1999; 284(5420): 1664-6.

PubMed Abstract | Publisher Full Text | F1000 Recommendation

22. F Abbaszade I, Liu RQ, Yang F, et al.: Cloning and characterization of ADAMTS11, an aggrecanase from the ADAMTS family. J Biol Chem. 1999; 274(33):

$23443-50$

PubMed Abstract | Publisher Full Text | F1000 Recommendation

23. F Stanton $\mathrm{H}$, Rogerson FM, East $\mathrm{CJ}$, et al.: ADAMTS5 is the major Frecanase in mouse cartilage in vivo and in vitro. Nature. 2005; 434(7033): $648-52$.

PubMed Abstract | Publisher Full Text | F1000 Recommendation

24. F Glasson SS, Askew R, Sheppard B, et al.: Deletion of active ADAMTS5 revents cartilage degradation in a murine model of osteoarthritis. Nature. 2005; 434(7033): 644-8.

PubMed Abstract | Publisher Full Text | F1000 Recommendation

25. F Henry SP, Liang S, Akdemir KC, et al:: The postnatal role of Sox9 in cartilage. J Bone Miner Res. 2012; 27(12): 2511-25.

PubMed Abstract | Publisher Full Text | Free Full Text | F1000 Recommendation

26. F Davidson ENB, Vitters EL, Bennink MB, et al.: Inducible chondrocyte-specific overexpression of BMP2 in young mice results in severe aggravation of osteophyte formation in experimental OA without altering cartilage damage. Ann Rheum Dis. 2015; 74(6): 1257-64.

PubMed Abstract | Publisher Full Text | F1000 Recommendation

27. F Karsdal MA, Madsen SH, Christiansen C, et al:: Cartilage degradation is fully reversible in the presence of aggrecanase but not matrix metalloproteinase activity. Arthritis Res Ther. 2008; 10(3): R63.

PubMed Abstract | Publisher Full Text | Free Full Text | F1000 Recommendation

28. F Botter SM, Glasson SS, Hopkins B, et al.: ADAMTS5-/- mice have less subchondral bone changes after induction of osteoarthritis through surgical instability: implications for a link between cartilage and subchondral bone changes. Osteoarthritis Cartilage. 2009; 17(5): 636-45.

PubMed Abstract | Publisher Full Text | F1000 Recommendation

29. Poole CA, Flint MH, Beaumont BW: Chondrons extracted from canine tibial cartilage: preliminary report on their isolation and structure. J Orthop Res. 1988; 6(3): 408-19.

PubMed Abstract | Publisher Full Text

30. Poole CA, Ayad S, Schofield JR: Chondrons from articular cartilage: I. Immunolocalization of type VI collagen in the pericellular capsule of isolated canine tibial chondrons. J Cell Sci. 1988; 90(Pt 4): 635-43. PubMed Abstract

31. Poole CA, Wotton SF, Duance VC: Localization of type IX collagen in chondrons isolated from porcine articular cartilage and rat chondrosarcoma. Histochem $\mathrm{J}$. 1988; 20(10): 567-74.

PubMed Abstract | Publisher Full Tex

32. Poole CA, Honda T, Skinner SJ, et al:: Chondrons from articular cartilage (II): Analysis of the glycosaminoglycans in the cellular microenvironment of isolated canine chondrons. Connect Tissue Res. 1990; 24(3-4): 319-30. PubMed Abstract | Publisher Full Text

33. F Poole CA, Matsuoka A, Schofield JR: Chondrons from articular cartilage. III. Morphologic changes in the cellular microenvironment of chondrons isolated from osteoarthritic cartilage. Arthritis Rheum. 1991; 34(1): 22-35. PubMed Abstract | Publisher Full Text | F1000 Recommendation

34. Poole CA: Articular cartilage chondrons: form, function and failure. $J$ Anat 1997; 191(Pt 1): 1-13. PubMed Abstract | Publisher Full Text | Free Full Text

35. Hunziker EB, Michel M, Studer D: Ultrastructure of adult human articular cartilage matrix after cryotechnical processing. Microsc Res Tech. 1997; 37(4): $271-84$

PubMed Abstract | Publisher Full Text

36. $\mathrm{Hu} \mathrm{K}, \mathrm{Xu} \mathrm{L}, \mathrm{Cao} \mathrm{L}$, et al.: Pathogenesis of osteoarthritis-like changes in the joints of mice deficient in type IX collagen. Arthritis Rheum. 2006; 54(9): 2891-900.

PubMed Abstract | Publisher Full Text

37. F Alexopoulos LG, Youn I, Bonaldo P, et al:: Developmental and osteoarthritic changes in Col6a1-knockout mice: biomechanics of type VI collagen in the cartilage pericellular matrix. Arthritis Rheum. 2009; 60(3): 771-9. PubMed Abstract | Publisher Full Text | Free Full Text | F1000 Recommendation

38. F Wadhwa S, Embree M, Ameye L, et al.: Mice deficient in biglycan and fibromodulin as a model for temporomandibular joint osteoarthritis. Cells Tissues Organs. 2005; 181(3-4): 136-43. PubMed Abstract | Publisher Full Text | F1000 Recommendation

39. F Wadhwa S, Embree MC, Kilts T, et al:: Accelerated osteoarthritis in the temporomandibular joint of biglycan/fibromodulin double-deficient mice. Osteoarthritis Cartilage. 2005; 13(9): 817-27.

PubMed Abstract | Publisher Full Text | F1000 Recommendation

40. F van der Weyden L, Wei L, Luo J, et al: Functional knockout of the matrilin-3 gene causes premature chondrocyte maturation to hypertrophy and increases bone mineral density and osteoarthritis. Am J Pathol. 2006; 169(2): 515-27. PubMed Abstract | Publisher Full Text | Free Full Text | F1000 Recommendation

41. F Borochowitz ZU, Scheffer D, Adir V, et al:: Spondylo-epi-metaphysea dysplasia (SEMD) matrilin 3 type: homozygote matrilin 3 mutation in a novel form of SEMD. J Med Genet. 2004; 41(5): 366-72.

PubMed Abstract | Publisher Full Text | Free Full Text | F1000 Recommendation

42. Hecht JT, Nelson LD, Crowder E, et al:: Mutations in exon 17B of cartilage oligomeric matrix protein (COMP) cause pseudoachondroplasia. Nat Genet. 1995; 10(3): 325-9.

PubMed Abstract | Publisher Full Text

43. Muragaki $\mathrm{Y}$, Mariman EC, van Beersum SE, et al.: A mutation in the gene encoding the alpha 2 chain of the fibril-associated collagen IX, COL9A2, causes multiple epiphyseal dysplasia (EDM2). Nat Genet. 1996; 12(1): 103-5. PubMed Abstract | Publisher Full Text

44. F Mustafa Z, Chapman K, Irven C, et al.: Linkage analysis of candidate genes as susceptibility loci for osteoarthritis-suggestive linkage of COL9A1 to female hip osteoarthritis. Rheumatology (Oxford). 2000; 39(3): 299-306. PubMed Abstract | Publisher Full Text | F1000 Recommendation

45. F Bönnemann CG, Cox GF, Shapiro F, et al.: A mutation in the alpha 3 chain of type IX collagen causes autosomal dominant multiple epiphyseal dysplasia with mild myopathy. Proc Natl Acad Sci U S A. 2000; 97(3): 1212-7. PubMed Abstract | Publisher Full Text | Free Full Text | F1000 Recommendation

46. F Czarny-Ratajczak M, Lohiniva J, Rogala $\mathrm{P}$, et al.: A mutation in COL9A1 causes multiple epiphyseal dysplasia: further evidence for locus heterogeneity. Am J Hum Genet. 2001; 69(5): 969-80. PubMed Abstract | Publisher Full Text | Free Full Text | F1000 Recommendation

47. Lee GM, Loeser RF: Interactions of the chondrocyte with its pericellular matrix. Cell Mater. 1998; 8: 135-149.

Reference Source

48. F Gogolla N, Caroni $\mathrm{P}$, Lüthi A, et al.: Perineuronal nets protect fear memories rom erasure. Science. 2009; 325(5945): 1258-61.

PubMed Abstract | Publisher Full Text | F1000 Recommendation

49. F Vonk LA, de Windt TS, Kragten AHM, et al.: Enhanced cell-induced articular cartilage regeneration by chondrons; the influence of joint damage and harvest site. Osteoarthritis Cartilage. 2014; 22(11): 1910-7. PubMed Abstract | Publisher Full Text | F1000 Recommendation

50. F Smeriglio $\mathrm{P}$, Dhulipala L, Lai JH, et al:: Collagen VI enhances cartilage tissue generation by stimulating chondrocyte proliferation. Tissue Eng Part A. 2015; 21(3-4): 840-9.

PubMed Abstract | Publisher Full Text | F1000 Recommendation

51. F Zelenski NA, Leddy HA, Sanchez-Adams J, et al:: Type VI Collagen Regulates Pericellular Matrix Properties, Chondrocyte Swelling, and Mechanotransduction in Mouse Articular Cartilage. Arthritis Rheumatol. 2015; 67(5): 1286-94.

PubMed Abstract | Publisher Full Text | Free Full Text | F1000 Recommendation 


\section{Open Peer Review}

\section{Current Peer Review Status:}

\section{Version 1}

Reviewer Report 28 August 2015

https://doi.org/10.5256/f1000research.6990.r10170

(C) 2015 Guilak F. This is an open access peer review report distributed under the terms of the Creative Commons Attribution License, which permits unrestricted use, distribution, and reproduction in any medium, provided the original work is properly cited.

\section{Farshid Guilak}

Duke University, Durham, NC, USA

Competing Interests: No competing interests were disclosed.

I confirm that I have read this submission and believe that I have an appropriate level of expertise to confirm that it is of an acceptable scientific standard.

Reviewer Report 28 August 2015

https://doi.org/10.5256/f1000research.6990.r10169

(C) 2015 Loeser R. This is an open access peer review report distributed under the terms of the Creative Commons Attribution License, which permits unrestricted use, distribution, and reproduction in any medium, provided the original work is properly cited.

\section{Richard Loeser}

University of North Carolina School of Medicine, Chapel Hill, NC, USA

Competing Interests: No competing interests were disclosed.

I confirm that I have read this submission and believe that I have an appropriate level of expertise to confirm that it is of an acceptable scientific standard. 
The benefits of publishing with F1000Research:

- Your article is published within days, with no editorial bias

- You can publish traditional articles, null/negative results, case reports, data notes and more

- The peer review process is transparent and collaborative

- Your article is indexed in PubMed after passing peer review

- Dedicated customer support at every stage

For pre-submission enquiries, contact research@f1000.com 